PROBLEMS

OF EDUCATION

IN THE $21^{\text {st }}$ CENTURY

Vol. 76, No. 5, 2018

\section{0}

\title{
EDUCATIONAL POTENTIAL OF ONLINE SOCIAL NETWORKS: GENDER AND CROSS-COUNTRY ANALYSIS
}

\author{
Gabriel Gorghiu \\ Valahia University Targoviste, Romania \\ E-mail: ggorghiu@gmail.com \\ Dragos Daniel Iordache \\ ICI Bucharest, Romania \\ University of Bucharest, Romania \\ E-mail: iordache@ici.ro
}

Costin Pribeanu

ICI Bucharest, Romania

Academy of Romanian Scientists, Romania

E-mail: pribeanu@ici.ro

Vincentas Lamanauskas

Šiauliai University, Lithuania

E-mail: v.lamanauskas@esf.su.It

\begin{abstract}
The social media technologies are blurring the boundaries between formal and informal/non-formal learning and provide new educational opportunities. Recent work shows that online social networks provide various kinds of educational support, such as social learning, informal/non-formal education, information, interaction, and collaboration. The aim of this research was to analyze the gender and cross-country differences in the perception of the educational opportunities provided by Facebook. The educational opportunities have been specified as a global factor that manifests along four dimensions: information, collaboration, personal development, and professional development. The model has been tested on two samples of university students, one from Romania and the other from Lithuania. An analysis of invariance has been carried on that shows that the educational opportunities model is invariant across groups. The results showed that female students have a higher perception of the educational opportunities provided by Facebook.
\end{abstract}

Keywords: cross-country differences, educational opportunities, gender differences, invariance analysis, online social networks.

\section{Introduction}

The widespread use of social media technologies among university students is blurring the boundaries between formal and informal/non-formal learning and provide new educational opportunities as regards learning in cooperation, learner's creativity, independence, and motivation (Manca \& Ranieri, 2013; Donlan, 2014, Greenhow \& Lewin, 2016). While the social networks are "moving" into the educational space, the context of learning is continuously expanding from school to home. For the institutions dedicated to adult and higher education, this means new challenges to cope with the formal and informal/non-formal education issues. 
The popularity of Facebook among university students stimulated the research on its potential educational benefits. Many studies highlighted various kinds of educational support, such as social learning, student support (orientation, mentoring, and adjustment to college), community building (campus community and participation in collective activities), informal/ non-formal education, information, interaction, and collaboration (Selwin, 2009; Mazman \& Usluel, 2010; Lamanauskas et al., 2013; Wang et al, 2014; Jong et al., 2015; Dhir et al., 2017).

The motives why and the way how people are using online social networks depend on several factors, including demographics. However, few studies exist that analyze the gender differences as regards the perceptions of using Facebook by university students and even fewer that analyze cross-country differences. If the variables under consideration are measures of an underlying model, an invariance analysis is needed to test if respondents are interpreting the variables in the same way (Steenkamp \& Baumgartner, 1998; Vandenberg \& Lance, 2000).

This research takes a multidimensional approach in order to analyze the gender and cross-country differences as regards the perception of the educational opportunities provided by Facebook. The educational opportunities have been specified as a global factor that manifests along four dimensions: information, collaboration, personal development, and professional development. The model has been tested on two samples, one from Lithuania and the second from Romania.

\section{Theoretical Background and Research Model}

\section{Related Work}

Given the high popularity of online social networks, the boundaries between formal, nonformal, and informal learning are blurring (Greenhow \& Lewin, 2016; Manca \& Ranieri, 2013). While, nonformal learning is related to the school, informal learning is related to situations that come up during other activities (Colley et al., 2003). Nonformal and informal learning are by their nature more learner-centered, being more influenced by demographic variables such as gender and age.

The large number of students who frequently use online social networks stimulated educators to analyze how these could be used as learning technologies for educational purposes (Mazman \& Usluel, 2010; Tess, 2013; von Krogh, 2012). Beyond the many advantages of using online social networks in education, changes are needed in the pedagogical theory and previous practices in order to offer and effective educational support. The emphasis should be on creative mode to use the social networks, and not only on how those tools simply improve the educational demarches or contribute to the reduction of the costs.

There are several studies (Brown \& Adler, 2008; Junco, 2012; Manca \& Ranieri, 2013; Manea et al., 2015) that analyze the educational support offered by online social networks and highlight their potential educational benefits such as: social learning, student support (orientation, mentoring), community building (campus community involving and participation in activities), interaction and collaboration, and expanding connections.

Through synchronous and asynchronous communication options, social networks may enhance students' collaboration involved in various educational tasks. Thus, social networks offer opportunities for joining in online communities, enhancing participation and collaboration, facilitating students' collaborative learning and creating understanding among students, by group-discussing, knowledge sharing and even developing students' research skills (Redecker et al, 2010).

For students, the use of social networks could be a good opportunity for personal development through various means: presenting themselves, building friendship networks, exchanging ideas and experiences related to different subjects, critical thinking, and participating in debates on various topics. At the same time, the reasons for using social networks in education are closely related to the teacher's responsibility to provide students with the necessary skills in a context of social learning.

\begin{tabular}{|l} 
PROBLEMS \\
OF EDUCATION \\
IN THE 21 $1^{\text {st }}$ CENTURY \\
Vol. 76, No. 5, 2018 \\
\hline 621
\end{tabular} 
Gabriel GORGHIU, Dragos Daniel IORDACHE, Costin PRIBEANU, Vincentas LAMANAUSKAS. Educational potential of online social networks: Gender and cross-country analysis

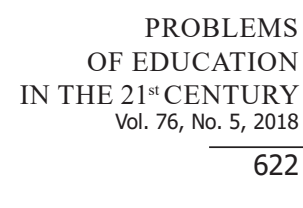

622

Manca and Ranieri (2013) identified three categories of pedagogical affordances of Facebook: mixing information and learning resources, hybridizing different expertise, and widening the context of learning. In fact, social media can be seen as a technology that can be exploited as a source of information with an important potential to be used to search for information about educational themes but with doubts or cautions about how people discern and assess credibility source of information (Westerman et al., 2012).

Providing the necessary resources for students with the aim to retrieve information and plan their future careers became a common task for the university career' centers. Online social networks represent a proper environment for enhancing networking opportunities, but at the same time, they have an important contribution to career development (Donlean, 2016). In addition, students may join public or private professional groups, or even they can outline a particular social network group in order to increase the preparation for their career development (Wong et al., 2014).

Analyzing the educational value of Facebook, Jong et al. (2014) found out that the main benefits are related to the comfort of use and to the opportunities to discuss about courses and learning issues, to interact with other students, and to access the teachers' postings. As shown by Kumar (2009), undergraduate students perceive the new technologies in e-learning as an opportunity for online discussions and engagement with their teachers and colleagues.

Donlan (2014) considers that the key to a productive academic use of social media technology is a change in the mindset among students, that requires also an effort from the part of the tutor to present the benefits of collaborative learning. His study explored the use of Facebook in an academic context and found that students had a clear interest in using Facebook for learning purposes.

The study of Bowman and Akcaoglu (2014) revealed two kinds of outcomes of joining a Facebook students group: cognitive outcomes, related to the academic performance and affective outcomes related to the dispositions towards the course environment. The results indicated that the students in the group using Facebook performed better, mainly because of the benefits of the membership (learning from each other). In this context, learning management systems are perceived by students as spaces for instruction rather than social learning environments and this is a reason for the use of Facebook to address the limitations of traditional teaching such as mass lectures.

Dhir et al. (2017) developed a multidimensional model of the Facebook educational affordances featuring four factors: Facebook use in math and science education, Facebook use in English education, info seeking and sharing, and academic uses of Facebook. The study also analyzed the influence of educational affordances on the intense use of Facebook, and the results indicate several educational affordances, such as information seeking, sharing of educational resources, various forms of collaboration, and career opportunities.

Gender differences may occur in the way students perceive the learning opportunities as well as in the way they learn. There are several studies that have analyzed the educational potential of online social networks in relation to gender differences. Thus, Mazman and Usluel (2011) analyzed the gender differences as regards the motives of using Facebook and found that men were more interested in making new contacts, while women showed higher preferences for maintaining existing relationships, academic purposes, and following a specific agenda. Makashvili et al. (2013) also analyzed the gender differences and found that male and female students had different motives for visiting Facebook: men rated passing time higher and women rated uploading pictures higher. Male respondents showed a higher interest to use Facebook extensively for making new friends and relationships while female students preferred keeping in touch with existing friends.

Kayaoglu (2016) analyzed the gender differences in Facebook usage on a sample of 354 university students. It was found that male students spent much more time on Facebook than female students, the difference being statistically significant. As regards the motives for using Facebook, his study didn't find significant differences. An interesting gender difference 
Gabriel GORGHIU, Dragos Daniel IORDACHE, Costin PRIBEANU, Vincentas LAMANAUSKAS. Educational potential of online social networks: Gender and cross-country analysis

was found as regards the preference to talk with people on Facebook vs. in person: most male students expressed the preference to talk on Facebook while most female students preferred to talk in person.

The study of Asterhan et al. (2012) explored the differences between female and male students involved in online discussion groups. The results showed that teacher guidance of synchronous, online discussions in classrooms was realizable and reasonably reached its intended goals. Also, training should be focused on acquiring various guidance strategies to augment their beneficial effects. Gender differences in favor of girls were found both on the argumentative as well as the collaborative dimension of the discussions.

Other studies (Krasnova et al. 2017) analyzed the gender effects on the intention to continue using online social networks and found that women are more motivated to maintain close ties and get social information while men are more motivated to get general information. They explained the differences by the correspondence with the relational interdependence of women and collective interdependence of men.

Based on data from a cross-country online survey of news media use, Nielsen and Schrøder (2014) realized comparative analysis of the relative importance of social media for news in Denmark, France, Germany, Italy, Japan, Spain, the UK, and the US, covering eight developed democracies with different media systems. The results showed a set of similarities in terms of the growing importance of social media as part of people's cross-media news habits, but also important country-to-country differences, in particular in terms of how widespread the more active and participatory forms of media use were. Of the eight countries, Germany and Japan have relatively low levels of social media use for news purposes, Italy, Spain, and to some extent the United States have higher levels, and Denmark, France, and the United Kingdom lie somewhere in between.

In Romania few approaches exist that analyze the gender differences in using social networks by university students. The study of Iordache (2017) analyzed the gender differences in the motives of using Facebook. The results showed that male students use Facebook to meet new people more frequently than female students do. At the same time, female students showed a higher interest to find out what happens in their university, to take part in groups of interest, and to maintain the existing social relations.

Pribeanu et al. (2017) examined the perceived usefulness of Facebook for university students by country and gender and found that in Romania female students have a higher perception of the Facebook usefulness than male students which is consistent with the results from other studies as regards the interest in the academic use of Facebook (Mazman \& Usluel, 2011). In Lithuania, male students have a higher perception of the information support information while female students have a higher perception as regards the collaboration support provided by Facebook.

\section{Research Model}

The educational opportunities have been conceptualized as a global factor (second-order construct) that manifests on four dimensions (first-order constructs): information, collaboration, personal development, and professional development (see Figure 1).

PROBLEMS

OF EDUCATION

IN THE $21^{\text {st }}$ CENTURY

Vol. 76, No. 5, 2018 
Gabriel GORGHIU, Dragos Daniel IORDACHE, Costin PRIBEANU, Vincentas LAMANAUSKAS. Educational potential of online social networks: Gender and cross-country analysis

PROBLEMS

OF EDUCATION

IN THE $21^{\text {st }}$ CENTURY

Vol. 76, No. 5, 2018

624

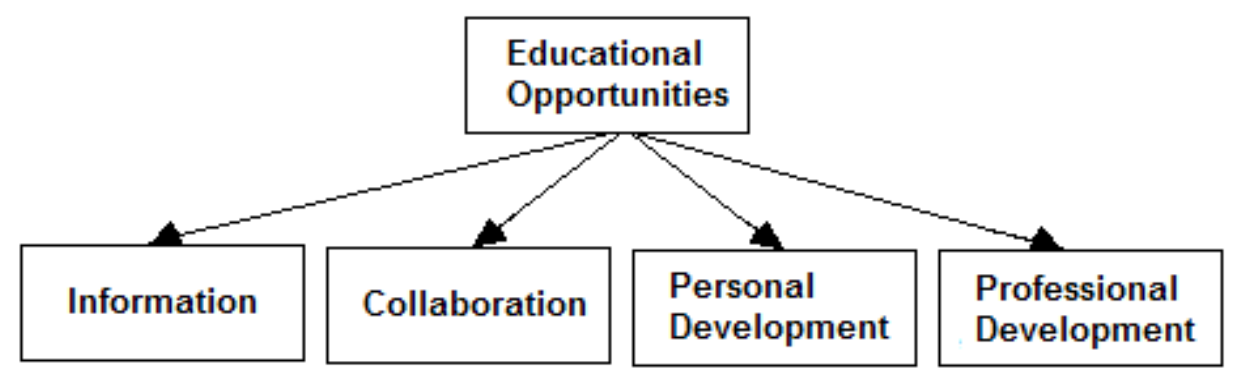

Figure 1. Research model.

The second-order factor model makes possible to distinguish between the contribution of each dimension, to analyze on two levels, and to compare the relative importance of each dimension. The operationalization of the constructs is presented in Table 1.

The opportunities for information (EDI) refer to the potential to find useful information as regards the learning resources, university-related events, life in university, and issues of interest. This educational potential has been frequently mentioned in the literature (Lamanauskas et al, 2013; Mazman \& Usluel, 2010; Manca \& Ranieri, 2013). The opportunities for collaboration (EDC) refer to the facilities for the creation and management of interest groups, and collaboration between colleagues. These opportunities have been mentioned in several studies (Dhir et al, 2017; Hamid et al, 2015; Mazman \& Usluel, 2010).

Table 1. Constructs and items.

\begin{tabular}{lll}
\hline Construct & Item & Statement \\
\hline EDI & EDI1 & Using Facebook, I can find useful information for my work \\
\hline EDC & EDI2 & Using Facebook, I can find useful resources for my work \\
\hline & The use of Facebook improves the participation in collective activities \\
\hline & EDC2 & The use of Facebook improves the communication between colleagues \\
\hline EDD & The use of Facebook improves the student group work & The use of Facebook stimulates the critical thinking \\
\hline & EDD2 & The use of Facebook stimulates the debate \\
\hline EDP & EDD3 & The use of Facebook stimulates the initiative \\
\hline & EDP2 & Using Facebook, I can find relevant information about my future profession \\
\hline
\end{tabular}

The opportunities for personal development (EDD) refer to the development of critical thinking, stimulation of debate, and initiative. This educational potential of the online social networks has been frequently discussed in the context of social learning (Selwin, 2009; Manca \& Ranieri, 2013). The opportunities for professional development (EDP) refer to the possibilities to find useful information related to the future profession. This kind of opportunities have been mainly mentioned in the context of informal education (Manca \& Ranieri, 2013).

The model has been previously tested on two samples of Romanian university students (Pribeanu et al., 2018) and a sample of Lithuanian university students (Lamanauskas et al., 2018). 
Gabriel GORGHIU, Dragos Daniel IORDACHE, Costin PRIBEANU, Vincentas LAMANAUSKAS. Educational potential of online social networks: Gender and cross-country analysis

\section{Empirical Research}

Method and Samples

Testing the multidimensional model has been done according to the recommendations from literature (Koufteros et al, 2009; Marsh \& Hocevar, 1985). Confirmatory Factor Analysis (CFA) with AMOS for Windows software (Arbuckle, 2007) was applied to test the measurement models.

Data analysis was carried out using the SPSS for Windows. Each model has been analyzed for dimensionality, the internal consistency of the scale, and convergent validity (Anderson \& Gerbing, 1988; Fornell \& Larcker, 1981; Hair et al., 2010). Since the dimensions are supposed to be highly correlated (Koufteros et al, 2009), discriminant validity is not so relevant here. The model fit was assessed through commonly used goodness-of-fit indices (Hair et al., 2010): the $\chi^{2}$ statistic, $\chi^{2} /$ df ratio, Tucker-Lewis Index (TLI), Comparative Fit Index (CFI), Root Mean Square Error of Approximation (RMSEA), and Standardized Root Mean Square Residual (SRMR).

As regards the invariance analysis, a multi-group CFA (MGCFA) using AMOS for Windows has been conducted that is based on testing a hierarchical series of nested models, starting with a baseline model that fits all the samples together. The parameters are freely estimated, and a baseline chi-square value is derived. Metric invariance tests if the factor loadings are equivalent across groups (equality of scaling units). Metric invariance enables the comparison of the observed scores. The scalar invariance tests the equality of the intercepts (origin of the scale) across groups. Scalar invariance enables the comparison of latent mean scores.

Prior to carrying on the multi-group CFA, the model has been tested and validated on each group, in order to check the configural invariance. Configural invariance means that in each group the dimensions are perceived in a similar way (same pattern of free and fixed factor loadings on the items).

The first sample included 211 university students (22 male and 190 female) from two Lithuanian universities. The age was varying between 15 and 46 years with a mean of 23.5 years $(S D=6.03)$. The mean number of Facebook friends is $473.23(S D=446.19)$ out of which 87.95 $(S D=11.81)$ are university students. The time spent daily on Facebook is on average 114.48 min. $(S D=148.43)$. The second sample included 567 university students (264 male and 303 female) from two Romanian universities. The age was varying between 18 and 59 years with a mean of 22.7 years $(S D=6.53)$. The mean number of Facebook friends is $913.26(S D=948.18)$, out of which $74.69(S D=137.95)$ are university students, and the time spent daily on Facebook is on average $67.99 \mathrm{~min}$. $(S D=67.65)$.

The participants have been asked to answer some general questions, and then to evaluate several statements, using a 7-point Likert scale.

\section{Model Testing Results}

The initial methodological approach has been carried on an invariance analysis on four groups, according to the country (Lithuania and Romania) and gender (male / female students). Since the group of Lithuanian male students was too small for confirmatory factor analysis $(N=22)$, two analyses have been carried on:

- Gender analysis for the sample of Romanian university students $(N=567)$

- Cross-country analysis for the samples of Romanian and Lithuanian university female students $(N=493)$.

Overall, three groups are considered: Romanian male students $(N=264)$, Romanian female students $(N=303)$, and Lithuanian female students $(N=190)$. The model testing results for the three samples are presented in Figure 2. 
Gabriel GORGHIU, Dragos Daniel IORDACHE, Costin PRIBEANU, Vincentas LAMANAUSKAS. Educational potential of online social networks: Gender and cross-country analysis

PROBLEMS

OF EDUCATION IN THE $21^{\text {st }}$ CENTURY Vol. 76, No. 5,2018

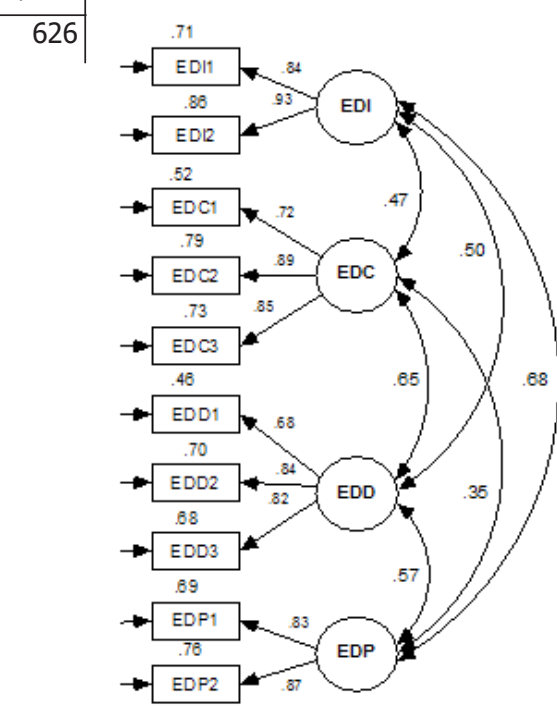

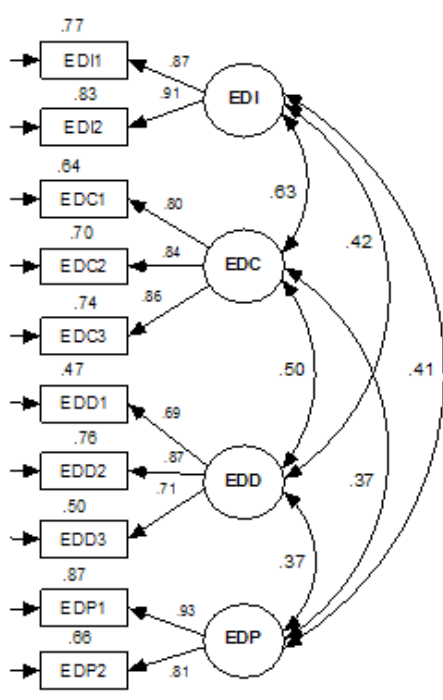

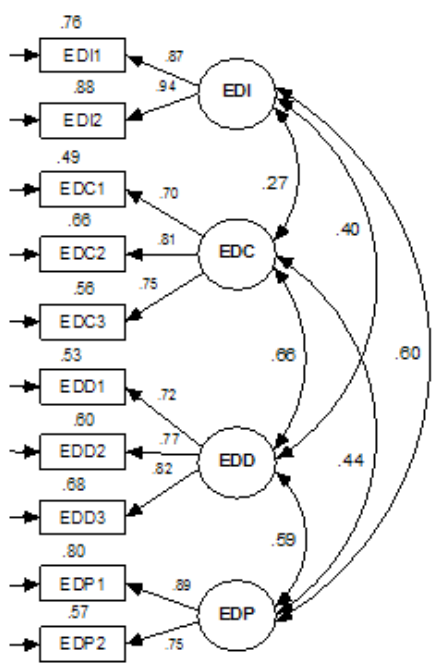

\section{Figure 2. Model testing results: a) $\mathrm{RO} / \mathrm{M}(N=264)$, b) RO/F $(N=303), \mathrm{c}) \mathrm{LT} / \mathrm{F}$ $(N=190)$.}

As it could be observed, all item loadings are over 0.6 which proves the unidimensionality of each dimension (first-order constructs). The correlation coefficients between the four dimensions are statistically significant in all samples. Also, all dimensions have convergent validity, since the composite reliability $\mathrm{CR}$ is over 0.7 and the average variance extracted AVE is over 0.5 . The scale reliability for the three samples is very good, as shown in Table 2 .

Table 2. Scale reliability (Cronbach's alpha).

\begin{tabular}{lccccc}
\hline Sample & N & EDI & EDC & EDD & EDP \\
\hline RO/M & 264 & .875 & .0 .856 & .821 & .841 \\
\hline RO/F & 303 & .887 & .867 & .797 & .864 \\
\hline LT/F & 190 & .893 & .797 & .807 & .833 \\
\hline
\end{tabular}

The model testing results indicated an acceptable fit of the measurement models with the data, as shown in Table 3.

Table 2. Goodness-of-Fit (GOF) indices.

\begin{tabular}{llllllllll}
\hline Group & $\boldsymbol{N}$ & $\chi^{2}$ & $\boldsymbol{p}$ & $\boldsymbol{d f}$ & $\chi^{2} / \boldsymbol{d f}$ & TLI & CFI & RMSEA & $\chi^{2} / \boldsymbol{d f}$ \\
\hline RO/M & 264 & 87.567 & .0001 & 29 & 3.02 & .938 & .960 & .088 & .0618 \\
\hline RO/F & 303 & 94.176 & .0001 & 29 & 3.247 & .937 & .959 & .086 & .0487 \\
\hline LT/F & 190 & 56.199 & .002 & 29 & 1.938 & .958 & .973 & .067 & .0412 \\
\hline
\end{tabular}

The model testing results on the three samples brought evidence for the configural invariance of the groups in the two previously mentioned analyses (gender analysis and cross-country analysis) which, in turn, enabled further invariance analysis. 
Gabriel GORGHIU, Dragos Daniel IORDACHE, Costin PRIBEANU, Vincentas LAMANAUSKAS. Educational potential of online social networks: Gender and cross-country analysis

\section{Analysis of Gender Differences}

The unconstraint model tested a sample $(N=567)$ fitting the Romanian female and male samples. The testing results $(N=567)$ showed an acceptable fit of the model with the data: $\chi^{2}=149.466, d f=58, p=.0001, \chi^{2} / \mathrm{df}=2.577, \mathrm{TLI}=.943, \mathrm{CFI}=.963, \mathrm{SRMR}=.0777, \mathrm{RMSEA}=.057$.

Then the analysis of invariance tested the series of nested models for metric and scalar invariance. The results are presented in Table 3.

Table 3. Analysis of invariance results $(\mathrm{N}=567)$.

\begin{tabular}{llllllll}
\hline Model & df & CMIN & CFI & d DF & d CMIN & d CFI & $p$ \\
\hline Unconstraint & 58 & 149.466 & .960 & & & & \\
\hline Meas. weights & 64 & 193.434 & .964 & 6 & 11.692 & .004 & .603 \\
\hline Meas. intercepts & 74 & 217.721 & .948 & 10 & 24.287 & -.016 & .007 \\
\hline
\end{tabular}

The first step constrained the factor loadings (measurement weights) to be equivalent across groups. The model comparison shows a nonsignificant chi-square difference $\left(\Delta \chi^{2}=\right.$ 11.692, $\Delta \mathrm{df}=6, p=.603$ ), therefore the model exhibits metric invariance. This means that the model has been perceived in the same way in each group and enables the comparison of observed scores. The next step showed a significant chi-square difference $\left(\Delta \chi^{2}=24.287, \Delta \mathrm{df}=\right.$ $10, p=.007)$ and a CFI depreciation larger than .01 which means a lack of scalar invariance.

The metric invariance enables the comparison of the observed scores, which is presented in Table 4, together with the results of the $\operatorname{ANOVA}(1,565,566)$ test for significance.

Table 4. Gender differences (Romanian university students).

\begin{tabular}{lllllllllll}
\hline Gender & EDI1 & EDI2 & EDC1 & EDC2 & EDC3 & EDD1 & EDD2 & EDD3 & EDP1 & EDP2 \\
\hline Male & 3.84 & 3.78 & 4.10 & 4.62 & 4.70 & 3.44 & 3.85 & 3.55 & 3.42 & 3.00 \\
\hline Female & 4.36 & 4.26 & 4.47 & 4.82 & 5.01 & 3.80 & 4.01 & 3.82 & 3.75 & 3.16 \\
\hline $\mathrm{F}$ & 13.625 & 12.004 & 7.312 & 1.991 & 5.098 & 5.942 & 1.146 & 3.494 & 4.706 & 1.041 \\
\hline $\mathrm{p}$ & .0001 & .001 & .007 & .159 & .024 & .015 & .285 & .062 & .030 & .308 \\
\hline
\end{tabular}

As it could be noticed, the female students scored higher on all items. The differences are statistically significant for EDI1, EDI2 (both items measuring the information opportunities), EDC1 (improvement of the participation in collective activities), EDC3 (improvement of the student group work), EDD1 (stimulation of the critical thinking), EDP1 (relevant information for the future profession), and marginally significant for EDD3 (stimulation of the initiative).

\section{Analysis of Country Differences}

The unconstraint model tested a sample fitting the Lithuanian and Romanian female samples. The results showed an acceptable fit of the model with the data: $\chi^{2}=209.973, d f=58$, $p=.0001, \chi^{2} / \mathrm{df}=3.588, \mathrm{TLI}=.9437, \mathrm{CFI}=.963, \mathrm{SRMR}=.0412, \mathrm{RMSEA}=.058$.

Then the analysis of invariance tested the series of nested models for metric and scalar invariance. The results are presented in Table 5.

The first step constrained the factor loadings (measurement weight) to be equivalent across groups. The model comparison shows a nonsignificant chi-square difference $\left(\Delta \chi^{2}=\right.$ $6.175, \Delta \mathrm{df}=6, p=.404)$, therefore the model exhibits metric invariance. This enables the com- 
Gabriel GORGHIU, Dragos Daniel IORDACHE, Costin PRIBEANU, Vincentas LAMANAUSKAS. Educational potential of online social networks: Gender and cross-country analysis

PROBLEMS

OF EDUCATION

IN THE $21^{\text {st }}$ CENTURY Vol. 76, No. 5, 2018

628

parison of the observed scores. The next comparison showed a significant chi-square difference $\left(\Delta \chi^{2}=73.348, \Delta \mathrm{df}=10, p=.0001\right)$ and CFI depreciation larger than .01 which means a lack of scalar invariance (measurement intercepts are not equivalent).

Table 5. Analysis of invariance results $(\mathrm{N}=493)$.

\begin{tabular}{llllllll}
\hline Model & df & CMIN & CFI & d DF & d CMIN & d CFI & $p$ \\
\hline Unconstraint & 58 & 149.466 & .963 & & & & \\
\hline Meas. weights & 64 & 155.641 & .963 & 6 & 6.175 & .000 & .404 \\
\hline Meas. intercepts & 74 & 228.989 & .938 & 10 & 73.348 & -.025 & .000 \\
\hline
\end{tabular}

The comparison of observed scores is presented in Table 6, together with the results of the $\operatorname{ANOVA}(1,491,492)$ test for significance.

Table 6. Differences between countries (female university students).

\begin{tabular}{lllllllllll}
\hline Country & EDI1 & EDI2 & EDC1 & EDC2 & EDC3 & EDD1 & EDD2 & EDD3 & EDP1 & EDP2 \\
\hline LT/F & 3.46 & 3.34 & 4.58 & 4.47 & 4.97 & 3.69 & 4.12 & 4.03 & 3.71 & 3.37 \\
\hline RO/F & 4.36 & 4.26 & 4.47 & 4.82 & 5.01 & 3.80 & 4.01 & 3.82 & 3.75 & 3.16 \\
\hline $\mathrm{F}$ & 33.240 & 36.045 & .560 & 5.407 & .083 & .462 & .519 & 1.818 & .050 & 1.746 \\
\hline $\mathrm{p}$ & .0001 & .0001 & .454 & .020 & .773 & .497 & .472 & .178 & .823 & .187 \\
\hline
\end{tabular}

The Romanian female students scored higher the items related to the opportunities for information dimension (EDI1, EDI2). The differences are statistically significant. They also scored higher the items EDC2 (improved communication between colleagues), EDC3 (improvement of student group work), EDD1 (stimulation of the critical thinking), and EDP1 (relevant information for the future profession). The differences are statistically significant only for the items EDI1, EDI2, and EDC2)

Lithuanian female students scored higher the items EDC1 (improvement of the participation in collective activities), EDD2 (stimulation of the debate), EDD3 (stimulation of the initiative), and EDP2 (broader view on the future profession). None of these differences are statistically significant.

\section{Discussion}

This work brings more insights into the gender and cross-country differences as regards the educational potential of the online social networks. Previous work (Lamanauskas et al., 2018) analyzed the cross-country differences regardless the gender. Even when the groups are well-balanced, the results may be misleading since the gender differences in each country could compensate at country level. In this research we took an approach similar to that of Pribeanu et al., 2017), by analyzing the cross-country differences by gender.

Previous work showed that university students from Romania are more interested than Lithuanian students to use Facebook for getting access to shared resources and participating in group discussions (Iordache et al., 2015). The results of this study are confirming this situation in that Romanian female students are more confident in the information and collaboration opportunities provided by Facebook. The differences are statistically significant for the educational potential related to information and resources.

Overall, both Romanian and Lithuanian students are valuing more the information and collaboration opportunities than the personal and professional development opportunities. Al- 
though the differences are not significant, Lithuanian female students scored higher two of the opportunities for personal development, related to the stimulation of the debate and initiative.

PROBLEMS

OF EDUCATION

IN THE $21^{\text {st }}$ CENTURY

Vol. 76, No. 5, 2018

As regards the gender differences, Romanian female students scored higher on all items measuring the educational opportunities provided by Facebook. The gender differences are statistically significant for the opportunities related to information, resources, improvement of the participation in collective activities, improvement of the student group work, stimulation of the critical thinking, information for the future profession, and stimulation of the initiative. The results are confirming the findings of a previous recent study (Pribeanu et al., 2017) as regards the usefulness of Facebook for university students. In general, existing studies show that female students are more interested in using the online social networks for academic purposes (Mazman \& Usluel, 2011; Aterhan et al., 2012). The research conducted in other countries show that both women and men use social networks differently. The research carried out in Mauritius showed that female students more than male use online social networks for social purposes (Gokulsing, 2014). In addition, female students spend more time on SNSs than male, also using online social networks has a negative impact on their academic performance (Samuel, Edward, \& Edward, 2017). It is obvious that the conducted empirical research confirms once again the attitudes of the previous research showing, that there are significant gender differences between how men and women adopt and use technology in general (Mitchell, Klein, \& Balloun, 1996; Sanchez-Franco, Francisco, Ramos, \& Velicia, 2009).

There are some inherent limitations of this work. First of all, this is the first cross-country and gender analysis as regards the educational opportunities provided by Facebook as perceived by university students from Romania and Lithuania. Second, two of the educational opportunities dimensions are measured with only two items. Another limitation is the crosscountry comparison that is made on female students only.

\section{Conclusions}

This research contributes to a deeper understanding of the perceived educational opportunities provided by Facebook for Romanian and Lithuanian universities. The results are also bringing new evidence for the reliability and validity of the scale that exhibits configural and metric invariance across countries and gender.

Overall, the results of this research highlight the fact that university students exploit Facebook for educational purposes mainly for sharing resources and collaboration. Their perception is lower on the last two dimensions proposed by the current research - personal development and professional development. Teachers have the possibility to open various discussion groups in order to facilitate the students' involvement in academic discussions, to moderate the communication and to stimulate the reflective / critical thinking, initiative, and debate. In this respect, educators should be more active in exploiting the educational potential of online social networks.

\section{Note}

This study extends and refines a previous work (see Lamanauskas, V., Gorghiu, G., Iordache, D. D., \& Pribeanu, C. (2018)) by analyzing the cross-country differences by gender.

\section{References}

Anderson, J. C., \& Gerbing, D. W. (1988). Structural equation modeling in practice: A review and recommended two-step approach. Psychological Bulletin, 103 (3), 411-423.

Arbuckle, J. L. (2007). AMOS 16.0 user's guide. Amos Development Corporation. 
Gabriel GORGHIU, Dragos Daniel IORDACHE, Costin PRIBEANU, Vincentas LAMANAUSKAS. Educational potential of online social networks: Gender and cross-country analysis

\section{PROBLEMS \\ OF EDUCATION \\ IN THE $21^{\text {st }}$ CENTURY Vol. 76, No. 5, 2018 \\ 630}

Asterhan, C. S., Schwarz, B. B., \& Gil, J. (2012). Small-group, computer-mediated argumentation in middle-school classrooms: The effects of gender and different types of online teacher guidance. British Journal of Educational Psychology, 82 (3), 375-397.

Bowman, N. D., \& Akcaoglu, M. (2014). "I see smart people": Using Facebook to supplement cognitive and affective learning in the university mass lecture. Internet and the Higher Education, 23, 1-8.

Colley, H., Hodkinson, P., \& Malcolm, J. (2003). Informality and formality in learning: A report for the learning and skills research centre. London, LSRC.

Brown, J. S., \& Adler, R. P. (2008). Open education, the long tail, and learning 2.0. Educause Review, 43 (1), 16-20.

Dhir, A., Khalil, A., Lonka, K., \& Tsai, C.-C. (2017). Do educational affordances and gratifications drive intensive Facebook use among adolescents? Computers in Human Behavior, 68, 40-50.

Donelan, H. (2016). Social media for professional development and networking opportunities in academia. Journal of Further and Higher Education, 40 (5), 706-729.

Donlan, L. (2014). Exploring the views of students on the use of Facebook in university teaching and learning. Journal of Further and Higher Education, 38 (4), 572-588.

Fornell, C., \& Larcker, D. F. (1981). Evaluating structural equations models with unobservable variables and measurement error. Journal of Marketing Research, 18 (1), 39-50

Gokulsing, D. (2014). Gender differences in the use of social networking sites in the context of globalisation: The case of Mauritius. In: Abu, N. M. Wahid, \& Carmen Reaiche Amaro (Eds.), Proceedings of the Australian Academy of Business and Social Sciences conference 2014 (in partnership with The Journal of Developing Areas) (Kuala Lumpur, Malaysia August 25-26, 2014). Australian Academy of Business and Social Sciences. Retrieved from https://www.aabss.org.au/system/files/ published/AABSS2014_254.pdf.

Greenhow, C., \& Lewin, C. (2016). Social media and education: Reconceptualizing the boundaries of formal and informal learning. Learning, Media and Technology, 41 (1), 6-30.

Hair, J. F., Black, W. C., Babin, B. J., Anderson, R. E., \& Tatham, R. L. (2006). Multivariate data analysis. $6^{\text {th }}$ ed., Prentice Hall.

Hamid, S., Waycott, J., Kurnia, S., \& Chang, S. (2015). Understanding students' perceptions of the benefits of online social networking use for teaching and learning, Internet and Higher Education, $26,1-9$.

Iordache, D. D. (2017). Gender differences in the motives of using online social networks by university students. Proceedings of eLSE Conference2017, Bucharest, Romania, 27-28 April, 570-577.

Iordache, D. D., Pribeanu, C., Lamanauskas, V., \& Raguliene, L. (2015). Usage of Facebook by university students in Romania and Lithuania: A comparative study. Informatica Economică, 19 (1), 46-54.

Jong, B. S., Lai, C. H., Hsia, Y. T., Lin, T. W., \& Liao, Y. S. (2014). An exploration of the potential educational value of Facebook. Computers in Human Behavior, 32, 201-211.

Junco, R. (2012). The relationship between frequency of Facebook use, participation in Facebook activities, and student engagement. Computers \& Education, 58 (1), 162-171.

Jong, B. S., Lai, C. H., Hsia, Y. T., Lin, T. W., \& Liao, Y. S. (2014). An exploration of the potential educational value of Facebook. Computers in Human Behavior 32, 201-211.

Junco, R. (2012). The relationship between frequency of Facebook use, participation in Facebook activities, and student engagement. Computers \& Education, 58 (1), 162-171.

Kayaoglu, M. N. (2016). Gender differences in Facebook usage among EFL students. Participatory Design Research, Special Issue, 40-48.

Koufteros, X. A., Babbar, S., \& Kaighobadi, M. (2009). A paradigm for examining second-order factor models employing structural equation modeling. International Journal of Production Economics, $120(2), 633-652$.

Krasnova, H., Veltri, N., Eling, N., \& Buxmann, P. (2017). Why men and women continue to use social networking sites: The role of gender differences. The Journal of Strategiv Information Systems, 26 (4), 261-284.

Koufteros, X. A., Babbar, S., \& Kaighobadi, M. (2009). A paradigm for examining second-order factor models employing structural equation modeling. International Journal of Production Economics, 120 (2), 633-652.

Kumar, S. (2009). Undergraduate perceptions of the usefulness of Web 2.0 in higher education: Survey development. Proceedings of 8th European Conference on E-learning, 308-314. Retrieved from http://citeseerx.ist.psu.edu/viewdoc/summary?doi=10.1.1.645.4409. 
Gabriel GORGHIU, Dragos Daniel IORDACHE, Costin PRIBEANU, Vincentas LAMANAUSKAS. Educational potential of online social networks: Gender and cross-country analysis

Lamanauskas, V., Šlekiene, V., Raguliene, L., Iordache, D. D., Pribeanu, C., Bilek, M., Cavas, B., \& Mazurok, T. (2013). Social networking websites from the point of view of university students: A comparative analysis. Problems of Education in the $21^{\text {st }}$ Century, 57, 61-78.

Lamanauskas V., Gorghiu, G., Iordache, D. D., \& Pribeanu, C. (2018). Perception of educational potential of online social networks in Romania and Lithuania. In. M. Turčáni, Z. Balogh, M. Munk, J. Kapusta, L. Benko (Eds.), DIVAI 2018 - The 12 $2^{\text {th }}$ international scientific conference on Distance Learning in Applied Informatics (May 2-4, 2018, Šturovo) (pp. 91-102). The Netherlands: Wolters Kluwer.

Makashvili, M., Ujmajuridze, B., \& Amirejibi, T. (2013). Gender difference in the motives for the use of Facebook. Asian Journal for Humanities and Social Studies (AJHSS), 1 (03), 130-135.

Manca, S., \& Ranieri, M. (2013). Is it a tool suitable for learning? A critical review of the literature on Facebook as a technology-enhanced learning environment. Journal of Computer Assisted Learning, 29 (6), 487-504.

Manea, I. V., Gorghiu, G., \& Iordache, D. D. (2015). The educational potential of Facebook use by students in Romanian universities. Revista Română de Interacțiune Om-Calculator, 8 (3), 195-208.

Marsh, H. W., \& Hocevar, D. (1985). Application of confirmatory factor analysis to the study of selfconcept: first- and higher order factor models and their invariance across groups. Psychological Bulletin, 97 (3), 562-582.

Mazman, S. G., \& Usluel, Y. K. (2010). Modeling educational usage of Facebook. Computers \& Education, 55 (2), 444-453.

Mazman, S. G., \& Usluel, Y. K. (2011). Gender differences in using social networks TOJET: The Turkish Online Journal of Educational Technology, 10 (2), 133-139.

Mitchell, D. L., Klein, G., \& Balloun, J. L. (1996). Mode and gender effects on survey data quality. Information \& Management, 30 (1), 27-34.

Nielsen, R. K., \& Schrøder, K. C. (2014). The relative importance of social media for accessing, finding, and engaging with news: An eight-country cross-media comparison. Digital Journalism, 2 (4), 472-489.

Pribeanu, C., Balog A., Lamanauskas, V., \& Slekiene, V. (2017) Perceived usefulness of Facebook for university students: A gender analysis across two countries. In Mihaescu, M. C., \& Forbrig, P. (Eds.), Proceedings of RoCHI 2017, Craiova, 11-12 September, 81-86.

Pribeanu, C., Iordache D. D., \& Balog, A. (2018). Educational opportunities provided by the social networking websites: A multidimensional model. Proceedings of ELSE 2018 Conference, Bucharest 19-20 April, Vol 4, 216-223.

Redecker, C., Ala-Mutka, K., \& Punie, Y. (2010). Learning 2.0 - The impact of social media on learning in Europe. Policy brief. JRC Scientific and Technical Report. EUR JRC56958 EN. Retrieved from: http://ipts.jrc.ec.europa.eu/publications/pub.cfm?id=3099.

Samuel, A., Edward, A. A., \& Edward, A. (2017). Gender differences in social networking sites usage among students: Evidence from Koforidua technical university (KTU) Ghana. IJRDO-Journal of Social Science and Humanities Research, 2 (10), 1-21.

Sanchez-Franco, M. J., Francisco, A., Ramos, V., \& Velicia, F. (2009). The moderating effect of gender on relationship quality and loyalty toward internet service providers. Information \& Management, $46(3), 196-202$.

Selwyn, N. (2009). Faceworking: Exploring students' education-related use of Facebook. Learning, Media and Technology, 34 (2), 157-174.

Steenkamp, J. B. E., \& Baumgartner, H. (1998). Assessing measurement invariance in cross-national consumer research. Journal of Consumer Research, 25 (1), 78-90.

Tess, P. A. (2013). The role of social media in higher education classes (real and virtual) - A literature review. Computers in Human Behavior, 29, A60-A68.

Vandenberg, R. J., \& Lance, C. E. (2000). A review and synthesis of the measurement invariance literature: Suggestions, practices, and recommendations for organizational research. Organizational Research Methods, 3 (1), 4-70.

von Krogh, G. (2012). How does social software change knowledge management? Toward a strategic research agenda. The Journal of Strategic Information Systems, 21, 154-164.

Wang, R., Scow, P., Urquhart, C., \& Hardman, J. (2014). Tapping the educational potential of Facebook: Guidelines for use in higher education. Education and Information Technologies, 19, 21-39. 
Gabriel GORGHIU, Dragos Daniel IORDACHE, Costin PRIBEANU, Vincentas LAMANAUSKAS. Educational potential of online social networks: Gender and cross-country analysis

OF EDUC

IN THE $21^{\text {st }}$ CENTURY

Vol. 76, No. 5, 2018

632

Westerman, D., Spence, P. R., \& Van Der Heide, B. (2012). A social network as information: The effect of system generated reports of connectedness on credibility on Twitter. Computers in Human Behavior, 28, 199-206.

Wong, K., Kwan, R., Leung, K., \& Wang, F. L. (2014). Facebook's potential for personal, social, academic and career development for higher education students. International Journal of Innovation and Learning, 16 (2), 203-220.

Received: May 10, 2018

Accepted: September 18, 2018

Gabriel Gorghiu

PhD, Professor, Valahia University Targoviste, 2 Regele Carol I Blvd., 130024 Targoviste, Romania.

E-mail: ggorghiu@gmail.com

Dragos Daniel lordache

$\mathrm{PhD}$, Researcher, National Institute for Research and Development in Informatics - ICI Bucharest, Bd. Maresal Averescu nr. 8-10, 011455, Bucharest, Romania.

E-mail: iordache@ici.ro

Costin Pribeanu

(Corresponding author)
$\mathrm{PhD}$, Senior Researcher I, National Institute for Research and Development in Informatics - ICI Bucharest, Bd. Maresal Averescu nr. 8-10, 011455, Bucharest, Romania.

E-mail: Pribeanu@ici.ro

Website: http://rochi.ici.ro/pribeanu
Vincentas Lamanauskas
PhD, Professor, Senior Researcher, Research Institute, University of Šiauliai, P. Visinskio Street 25-119, LT-76351 Siauliai, Lithuania.

E-mail: v.lamanauskas@ef.su.It

Website: http://www.lamanauskas.puslapiai.lt/ https://www.facebook.com/ScientiaEducologica 